\title{
High expression of SH2B adaptor protein 1 (SH2B1) indicates poor prognosis in colorectal cancer
}

\author{
Linxi ZHANG ${ }^{1, *}$, Xiaowen XU ${ }^{1, *}$, Yamin PAN ${ }^{1, *}$, Fuao $\mathrm{CAO}^{2, *}$ \\ ${ }^{1}$ Shuguang Hospital Affiliated to Shanghai University of Traditional Chinese Medicine, Shanghai University of Traditional Chinese Medicine, \\ Shanghai, China; ${ }^{2}$ Department of Colorectal Surgery, Changhai Hospital, Second Military Medical University, Shanghai, China
}

*Correspondence: 13611753821@163.com; caofuao@me.com

${ }^{\#}$ Contributed equally to this work.

Received October 15, 2020 / Accepted December 1, 2020

\begin{abstract}
$\mathrm{SH} 2 \mathrm{~B} 1$, an adaptor protein associated with obesity, is closely related to the occurrence and development of a variety of tumors. To investigate the clinical significance of SH2B1 in colorectal cancer (CRC), expression of SH2B1 in colorectal normal tissues, adenomas, paracarcinoma tissues, carcinoma tissues, and metastatic tissues from 1003 CRC patients was detected by immunohistochemistry (IHC). The prediction power of SH2B1 for CRC prognosis was evaluated by KaplanMeier survival analysis and Cox regression model. Results revealed the expression of SH2B1 in carcinoma tissues was significantly higher than that in other tissues. High expression of SH2B1 was an independent risk factor for both disease-free survival (DFS) and disease-specific survival (DSS) and predicted unfavorable prognosis of CRC as well as poor chemotherapeutic response. Conclusively, $\mathrm{SH} 2 \mathrm{~B} 1$ can serve as an effective predictor for CRC survival and chemotherapeutic outcomes.
\end{abstract}

Key words: SH2B1, tumorigenesis, prognosis, colorectal cancer

SH2B1 (SRC homology 2 [SH2] B adaptor protein 1), located on chromosome $16 \mathrm{p} 11.2$, is an important body weight regulation protein. $\mathrm{SH} 2 \mathrm{~B} 1$ controls body weight by regulating signaling molecules related to fat storage, sugar utilization, energy balance, and body weight [1]. So, its deficiency can lead to stunting and obesity $[2,3]$. Apart from the metabolic function, SH2B1 has been proved to be highly expressed in a variety of cancer cells, such as esophageal cancer, lung cancer, gastric cancer, and colorectal cancer (CRC) [4-8]. And its clinical significance on tumor progression and prognosis has been reported in some cancers, especially in lung cancer [9]. However, few studies were executed on the significance of SH2B1 in CRC. SH2B1 was found to be highly expressed in CRC cell lines in vitro and its overexpression was related to CRC cell progression $[8,10]$. The objective of this study was to indicate the expression of $\mathrm{SH} 2 \mathrm{~B} 1$ in different tumor tissues from CRC patients and to clarify if SH2B1 expression in tumor tissues is prognostic and/or predictive for CRC. This study should be helpful for the prediction and targeted treatment of CRC.

\section{Patients and methods}

Patients and specimens. Pathologically proven formalinfixed paraffin-embedded (FFPE) tissues containing adenoma $(n=33)$, paracancerous $(n=38)$, and cancerous $(n=1003)$ tissues were obtained from the surgically removed specimens of 1003 CRC patients, who received surgical resection at the Shanghai Hospital between January 2006 and November 2011. Patients who received preoperative chemotherapy or radiation were excluded from this study. Each patient's clinical characteristics including age, sex, tumor location, number of resected lymph nodes, differentiation grade, TNM staging (according to the American Joint Committee on Cancer Staging System, 7th edition), adjuvant chemotherapy, serum carcinoembryonic antigen (CEA), and carbohydrate antigen 199 (CA199) levels were collected. Moreover, FFPE tissues of CRC liver metastases $(n=17)$ and normal colorectal specimens $(n=36)$ were collected in the hospital. The follow-up examination of the 1003 CRC patients, containing the chest CT scans, abdominal ultrasonography, pelvic MRI/CT, colonoscopy, serous CEA, and CA199, was carried out every 6 to 12 months. A telephone interview was conducted every 6 to 12 months to gain information about the condition of the patients. This study was approved by the Institutional Review Committee of Shanghai Hospital. All participants signed a written informed consent form, giving permission for the biomaterials to be used in the study. 
Immunohistochemistry. Tissue microarrays (TMAs) containing the FFPE specimens were constructed by a commercial agent (Outdo Biotech, Shanghai, China). The examination of immunohistochemistry (IHC) was processed as previously described [11]. Rabbit anti-human SH2B1 polyclonal antibody (1:1,000, HPA076175, Sigma-Aldrich Co.) and secondary antibodies from the Elivision ${ }^{\mathrm{TM}}$ super HRP (Mouse/Rabbit) IHC Kit (kit-9922, Maxvision, Foshan, China) were used for incubation following the manufacturer's guidelines. For the minimum intra assay variation, the same individual researcher stained all slides.

Quantitative evaluation of SH2B1 immunostaining. Stained TMA slides were scanned by the Servicebio system (digital scanning via Pannoramic MIDI; 3Dhistech, Budapest, Hungary), and the CaseViewer software was used to evaluate the images under bright-field microscopy at a resolution of $\times 200$. H-score method was used for the quantification of SH2B1 expression. Immunostaining intensity of SH2B1 protein in a fixed field was assessed as negative ( 0$)$, weakly positive $(1+)$, moderately positive $(2+)$, and strongly positive $(3+)$. The percentage of epithelial cells at each staining intensity level was measured by the Image-Pro Plus 6.0 software (Media Cybernetics, Inc., Rockville, MD, USA). Five fields were selected randomly and the $\mathrm{H}$-score was calculated by multiplying the average percentage of positive cells by the corresponding staining intensity.

Statistical analysis. Pearson $\chi^{2}$ test and independent Student t-test (for continuous variables) were used for the descriptive summary of the clinicopathological features. An independent sample t-test was used to compare the differences in IHC score of SH2B1 between different tissues. The optimal cut-off value of the IHC score was identified
A
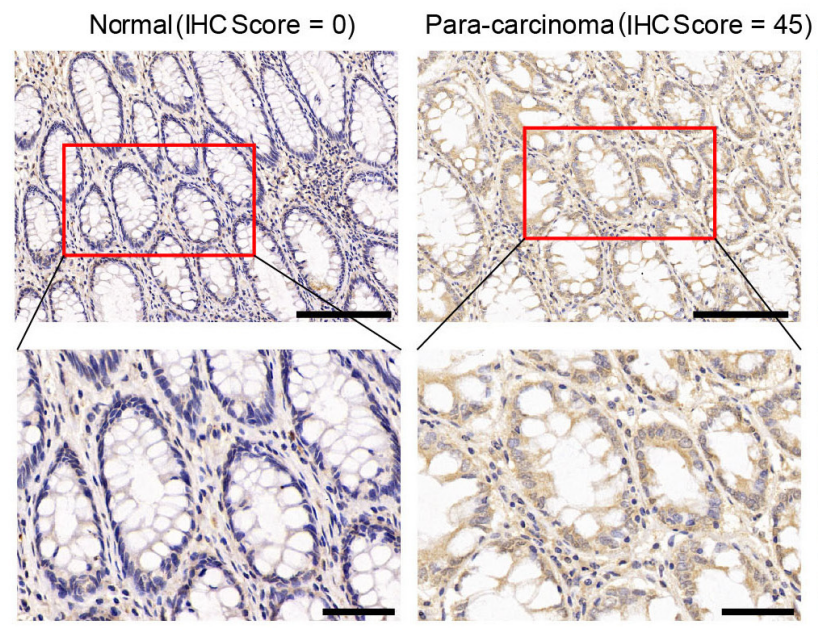

Metastasis $(\mathrm{IHC}$ Score $=150)$

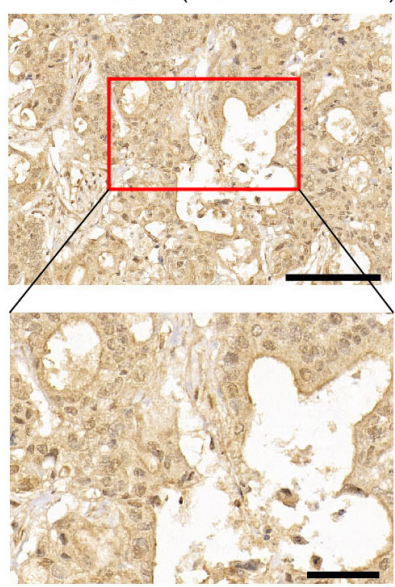

Carcinoma $(\mathrm{IHC}$ Score $=250)$

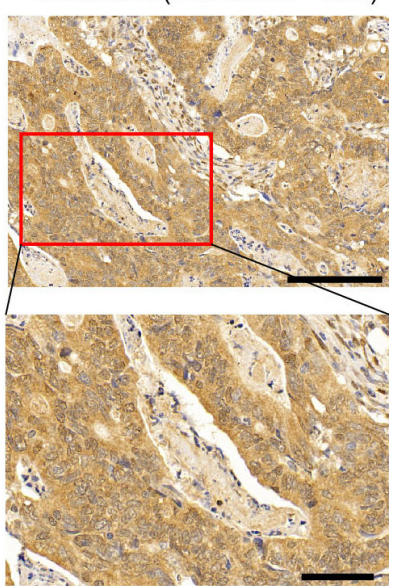

B
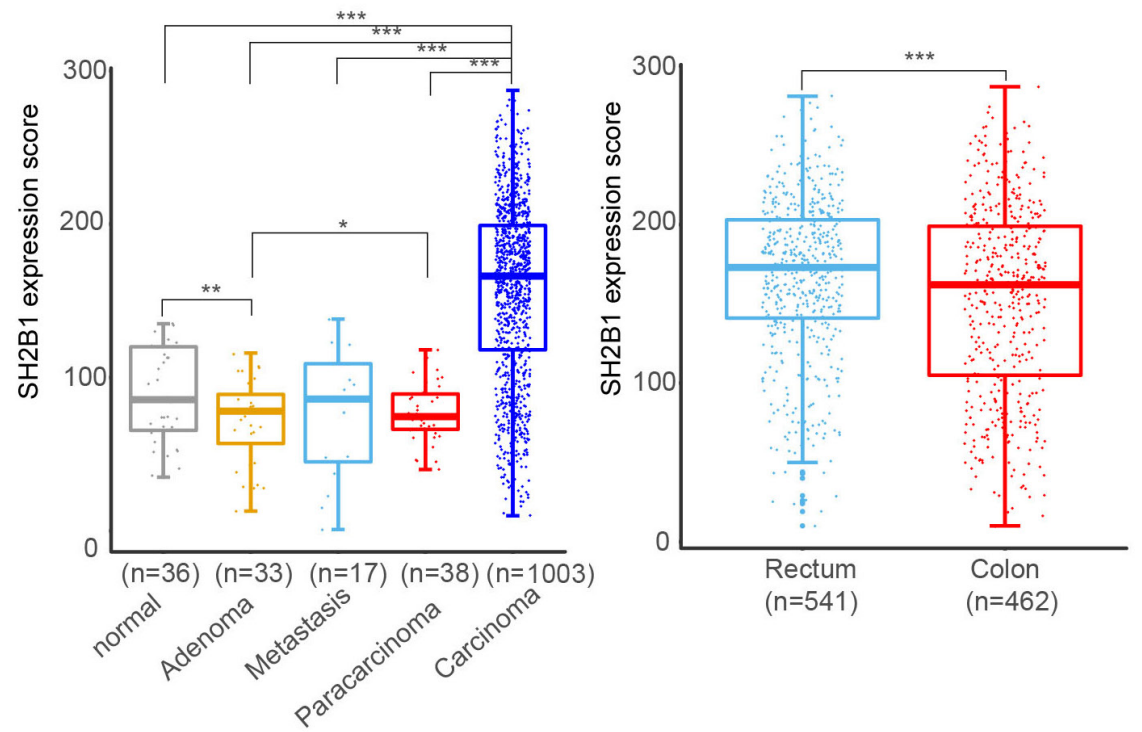

Figure 1. Expression pattern of SH2B1 protein in different tissues of CRC patients. A) Representative immunostainings of SH2B1 in colorectal normal tissues, adenomas, paracarcinoma, carcinoma, and metastatic tissues. Bar, $50 \mu \mathrm{m}$. B) Comparisons of epithelial SH2B1 expression in different tissues. ${ }^{*} \mathrm{p}<0.05 ;{ }^{* *} \mathrm{p}<0.01 ;{ }^{* * *} \mathrm{p}<0.001$ 
by the Maxstat package for the stratification of subgroups. Kaplan-Meier analysis with log-rank test was performed to estimate disease-free survival (DFS) and disease-specific survival (DSS). Cox proportional hazards models were used to estimate the hazard ratios (HRs) and their $95 \%$ confidence intervals (CIs). All statistical analyses were performed by SPSS 21.0 and R 3.5.1. A p-value $<0.05$ was considered statistically significant.

\section{Results}

Elevated SH2B1 expression in the cytoplasm of CRC epithelial cells. To gain insights into the expression pattern of SH2B1 in different colorectal tissues, IHC analysis was performed to detect $\mathrm{SH} 2 \mathrm{~B} 1$ protein expression in colorectal normal tissues, adenomas, paracarcinoma, carcinoma, and metastatic tissues. SH2B1 was mainly expressed in the cytoplasm of epithelial cells. Different SH2B1 expression levels and the corresponding IHC scores are shown in
Figure 1A. The IHC score of epithelial SH2B1 expression was significantly higher in colorectal carcinoma tissues than in the other tissues $(\mathrm{p}<0.001$; Figure 1B). SH2B1 expression differences were also significant between colon and rectal carcinoma tissues $(\mathrm{p}<0.001$; Figure $1 \mathrm{~B})$.

Associations between the cytoplasm $\mathrm{SH} 2 \mathrm{~B} 1$ and patient features. $1003 \mathrm{CRC}$ patients were classified into two subgroups according to the IHC scores: high expression (IHC score $\geq 116$ ) and low expression (IHC score $<116$ ). Then the associations of SH2B1 expression with the clinicopathological characteristics of CRC patients were analyzed. As shown in Table 1, high expression of SH2B1 was associated with poor tissue differentiation $(\mathrm{p}<0.001)$, and this phenomenon existed in rectal cancer and colon cancer $(\mathrm{p}<0.001)$, respectively. Apart from tissue differentiation, $\mathrm{SH} 2 \mathrm{~B} 1$ expression was also related to the number of resected lymph nodes ( $\mathrm{p}=0.038$ ), but the phenomenon only existed in colon cancer $(\mathrm{p}=0.039)$. According to the results, it's inferred that SH2B1 may contribute to the progression of CRC.

Table1. Characteristics of patient with CRC dichotomized by SH2B1 expression.

\begin{tabular}{|c|c|c|c|c|c|c|c|c|c|}
\hline \multirow[b]{2}{*}{ Variables } & \multicolumn{3}{|c|}{ All $(n=1003)$} & \multicolumn{3}{|c|}{ Colon $(n=462)$} & \multicolumn{3}{|c|}{ Rectum $(n=541)$} \\
\hline & $\begin{array}{l}\text { SH2B1 }^{L} \\
(n=216)\end{array}$ & $\begin{array}{l}\mathrm{SH}_{2 B 1}^{\mathrm{H}} \\
(\mathrm{n}=787)\end{array}$ & p-value & $\begin{array}{l}\text { SH2B1 }^{\mathrm{L}} \\
(\mathrm{n}=131)\end{array}$ & $\begin{array}{l}\mathrm{SH}_{2 B 1}^{\mathrm{H}} \\
(\mathrm{n}=331)\end{array}$ & p-value & $\begin{array}{c}\text { SH2B1 }^{\mathrm{L}} \\
(\mathrm{n}=85)\end{array}$ & $\begin{array}{l}\text { SH2B1 } \\
(n=456)\end{array}$ & p-value \\
\hline Age, mean $\pm S D$ & $60.83 \pm 11.83$ & $61.02 \pm 12.65$ & 0.843 & $60.90 \pm 12.64$ & $62.69 \pm 14.00$ & 0.203 & $60.73 \pm 10.54$ & $59.81 \pm 11.44$ & $0.491^{\star *}$ \\
\hline \multicolumn{10}{|l|}{ Sex, n (\%) } \\
\hline Male & $121(56.0)$ & $478(60.7)$ & 0.210 & $72(55.0)$ & $187(56.5)$ & 0.765 & $49(53.4)$ & $291(63.8)$ & $0.280^{*}$ \\
\hline Female & $95(44.0)$ & $309(39.3)$ & & $59(45.0)$ & $144(43.5)$ & & $36(31.6)$ & $165(36.2)$ & \\
\hline \multicolumn{10}{|c|}{ Differential grade, n (\%) } \\
\hline Well & $47(21.8)$ & $71(9.0)$ & $<0.001$ & $34(26.0)$ & $47(14.2)$ & $<0.001$ & $13(15.3)$ & $24(5.3)$ & $<0.001^{\star * *}$ \\
\hline Moderate & $159(73.6)$ & $681(86.5)$ & & $90(68.7)$ & $263(79.5)$ & & $69(81.2)$ & $418(91.7)$ & \\
\hline Poor & $0(0.0)$ & $26(3.3)$ & & $0(0.0)$ & $14(4.2)$ & & $0(0.0)$ & $12(2.6)$ & \\
\hline Missing & $10(4.6)$ & $9(1.2)$ & & $7(5.3)$ & $7(2.1)$ & & $3(3.5)$ & $2(0.4)$ & \\
\hline \multicolumn{10}{|c|}{ Lymph nodes, n (\%) } \\
\hline$<12$ & $163(75.5)$ & $650(82.6)$ & 0.038 & $88(67.2)$ & $258(77.9)$ & 0.039 & $75(88.2)$ & $392(86.0)$ & $0.797^{\star}$ \\
\hline$\geq 12$ & $53(24.5)$ & $135(17.2)$ & & $43(32.8)$ & $72(21.8)$ & & $10(11.8)$ & $63(13.8)$ & \\
\hline Missing & & $2(0.3)$ & & & $1(0.3)$ & & & $1(0.2)$ & \\
\hline \multicolumn{10}{|c|}{ TNM stage, n (\%) } \\
\hline $\mathrm{I}$ & $10(4.6)$ & $128(16.3)$ & 0.788 & $3(2.3)$ & $30(9.1)$ & 0.568 & $0(0.0)$ & $1(0.2)$ & $0.957^{\star \star *}$ \\
\hline II & $141(65.3)$ & $364(46.3)$ & & $83(63.4)$ & $162(48.9)$ & & $75(88.2)$ & $392(86.0)$ & \\
\hline III & $65(30.1)$ & $295(37.5)$ & & $45(34.4)$ & $139(42.0)$ & & $10(11.8)$ & $63(13.8)$ & \\
\hline \multicolumn{10}{|c|}{ Chemotherapy, n (\%) } \\
\hline Yes & $184(85.2)$ & $631(80.2)$ & 0.095 & $109(83.2)$ & $258(77.9)$ & 0.207 & $75(88.2)$ & $373(81.8)$ & $0.149^{*}$ \\
\hline No & $32(14.8)$ & $156(19.8)$ & & $22(16.8)$ & $73(22.1)$ & & $10(11.8)$ & $83(18.2)$ & \\
\hline \multicolumn{10}{|c|}{ Serum CEA, n (\%) } \\
\hline$<5 \mathrm{ng} / \mathrm{ml}$ & $135(62.5)$ & $485(61.6)$ & 0.652 & $79(60.3)$ & $192(58.0)$ & 0.651 & $56(65.9)$ & $293(64.3)$ & $0.738^{\star}$ \\
\hline$\geq 5 \mathrm{ng} / \mathrm{ml}$ & $81(37.5)$ & $299(38.0)$ & & $52(39.7)$ & $139(42.0)$ & & $29(34.1)$ & $160(35.1)$ & \\
\hline Missing & & $3(0.4)$ & & & & & & $3(0.7)$ & \\
\hline \multicolumn{10}{|c|}{ Serum CA199, n (\%) } \\
\hline$<37 \mathrm{U} / \mathrm{ml}$ & $182(84.3)$ & $674(85.6)$ & 0.637 & $108(82.4)$ & $268(81.0)$ & 0.713 & $74(87.1)$ & $406(89.0)$ & $0.675^{*}$ \\
\hline$\geq 37 \mathrm{U} / \mathrm{ml}$ & $34(15.7)$ & $111(14.1)$ & & $23(17.6)$ & $63(19.0)$ & & $11(12.9)$ & $48(10.5)$ & \\
\hline Missing & & $2(0.3)$ & & & & & & $2(0.4)$ & \\
\hline
\end{tabular}

Abbreviations: CA199-carbohydrate antigen 199; CEA-carcinoembryonic antigen; CRC-colorectal cancer; SH2B1-Nicotinamide N-methyltransferase; SH2B1L-SH2B1 low expression; SH2B1H-SH2B1 high expression. Notes: ${ }^{*} \chi^{2}$ or Fisher's exact test, missing values are excluded for all statistic tests; ${ }^{* *}$ Student's t-test; ${ }^{* *}$ Mann-Whitney $U$ test (nonparametric), missing values are excluded for all statistic tests 
Epithelial SH2B1 expression predicts unfavorable survival of CRC patients. Then, the prognostic value of epithelial SH2B1 expression in CRC was further studied. First, Kaplan-Meier survival analysis was used to estimate the difference of DFS and DSS between the two subgroups, which were stratified by SH2B1 expression level. KaplanMeier curves and log-rank tests revealed that high SH2B1 expression was significantly associated with shorter DFS $(\mathrm{p}<0.001)$ and DSS $(\mathrm{p}<0.001)$ for CRC patients (Figure $2 \mathrm{~A})$. And it's consistently remained in colon cancer and rectal cancer (Figures 2B, 2C). Next, univariate Cox analysis was employed to screen factors, which were highly associated with DFS or DSS. As shown in Table 2, the expression of SH2B1 was significantly associated with both DFS $(\mathrm{p}<0.01)$ and DSS $(\mathrm{p}<0.001)$ of CRC patients; besides, TNM stage, chemotherapy treatment, serum CEA, and CA199 was associated with DFS of CRC patients. Moreover, SH2B1 expression was subjected to multivariate Cox regression analysis, taking TNM stage, chemotherapy treatment, serum CEA, and CA199 as covariates, to further explore the association of SH2B1 expression with DFS and DSS of CRC patients. The results showed that high SH2B1 expression in CRC was an independent risk factor for DFS (HR: 3.188; 95\% CI: 1.9735.149) and DSS (HR: 5.525; 95\% CI: 2.480-12.308), as shown in Table 2. What is more, high SH2B1 expression remained the independent risk factor when multivariate Cox regression analysis was carried out respectively in colon cancer and rectal cancer (Supplementary Tables S1 and S2).
Epithelial SH2B1 expression predicts the prognosis of patients with early-stage CRC. The relationship between SH2B1 expression and DFS/DSS among patients with earlierstage CRC (stage I/II) and among patients with later-stage CRC (stage III) was studied, respectively. Results showed that high SH2B1 expression was related to poorer DSS and DFS in early-stage CRC patients as well as in stage III CRC patients (all $\mathrm{p}<0.01$, Figure $3 \mathrm{~A}$ ). Similar results were found in colon cancer (all $\mathrm{p}<0.01$, Figure $3 \mathrm{~B}$ ) but not in rectal cancer (Figure 3C).

Epithelial SH2B1 expression predicts benefit from adjuvant chemotherapy for CRC patients. The association between SH2B1 expression and survival outcomes among patients with or without chemotherapy was further studied. In our cohort, almost all the stage III CRC patients (340/360) and stage II CRC patients who were diagnosed with adverse prognostic factors (412/505) received postoperative chemotherapy. For these stage II or stage III CRC patients who received chemotherapy, higher $\mathrm{SH} 2 \mathrm{~B} 1$ expression indicated shorter DSS and DFS (Figure 4). This result demonstrates that SH2B1 expression may predict the chemotherapeutic response of stage II/III CRC patients.

\section{Discussion}

In previous studies, SH2B1 was mainly associated with type 2 diabetes and obesity $[12,13]$. It is remarkable that compared with the general population, people with type 2
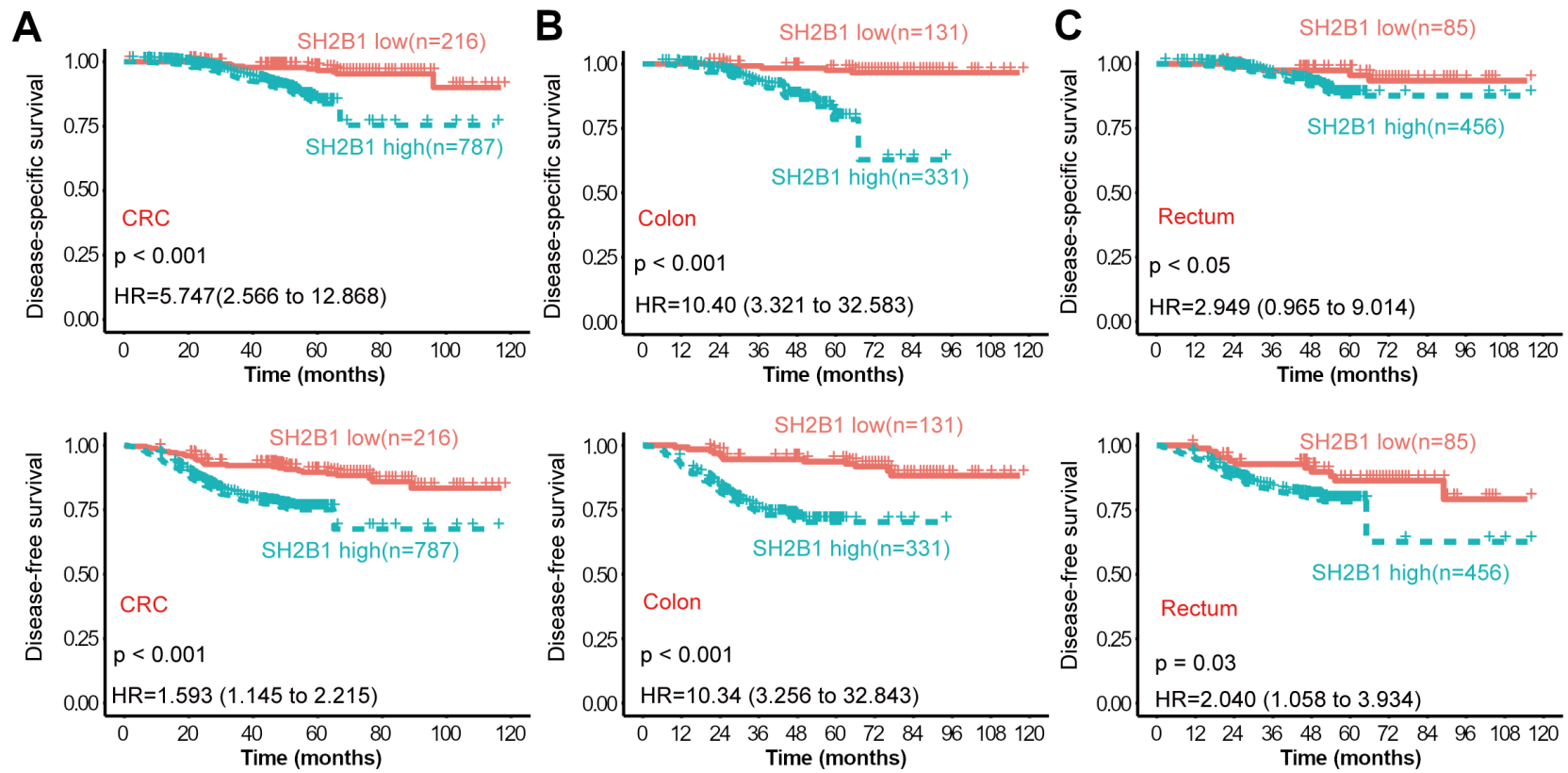

Figure 2. Kaplan-Meier survival curves showing a comparison of DFS and DSS between high and low SH2B1 expression subgroups. A) Comparisons of DFS and DSS between SH2B1-high and SH2B1-low subgroups in CRC patients. B) Comparisons of DFS and DSS between SH2B1-high and SH2B1low subgroups in colon cancer patients. C) Comparisons of DFS and DSS between SH2B1-high and SH2B1-low subgroups in rectal cancer patients. Log-rank p-values and hazard ratios (HRs) from Kaplan-Meier analysis with the log-rank test are shown. 
Table2. Cox regression analysis of immunohistochemistry SHP2B1 expression and clinicopathological covariates in the CRC patients.

\begin{tabular}{|c|c|c|c|c|c|c|c|c|}
\hline \multirow{3}{*}{ Variables } & \multicolumn{4}{|c|}{ Disease-specific survival } & \multicolumn{4}{|c|}{ Disease-free survival } \\
\hline & \multicolumn{2}{|c|}{ Univariate analysis } & \multicolumn{2}{|c|}{ Multivariate analysis } & \multicolumn{2}{|c|}{ Univariate analysis } & \multicolumn{2}{|c|}{ Multivariate analysis } \\
\hline & HR $(95 \% \mathrm{CI})$ & p-value & HR $(95 \%$ CI $)$ & p-value & $\operatorname{HR}(95 \% \mathrm{CI})$ & p-value & HR (95\% CI) & p-value \\
\hline \multicolumn{9}{|l|}{ SH2B1 } \\
\hline \multirow[t]{2}{*}{ Low vs. High } & 5.747 & $<0.001$ & 5.525 & $<0.001$ & 1.593 & 0.006 & 3.188 & $<0.001$ \\
\hline & $(2.566-12.868)$ & & $(2.480-12.308)$ & & $(1.145-2.215)$ & & $(1.973-5.149)$ & \\
\hline \multicolumn{9}{|l|}{ Sex } \\
\hline \multirow[t]{2}{*}{ Male vs. Female } & 0.844 & 0.463 & & & 0.916 & 0.549 & & \\
\hline & $(0.537-1.327)$ & & & & $(0.687-1.221)$ & & & \\
\hline \multicolumn{9}{|l|}{ Tumor location } \\
\hline \multirow[t]{2}{*}{ Colon vs. Rectum } & 1.204 & 0.410 & & & 1.139 & 0.367 & & \\
\hline & $(0.774-1.872)$ & & & & $(0.859-1.509)$ & & & \\
\hline \multicolumn{9}{|l|}{ Differential grade } \\
\hline \multirow[t]{2}{*}{ (Well+Moderate) vs. Poor } & 0.854 & 0.657 & & & 0.939 & 0.776 & & \\
\hline & $(0.425-1.716)$ & & & & $(0.601-1.453)$ & & & \\
\hline \multicolumn{9}{|l|}{ Lymph nodes, n (\%) } \\
\hline \multirow[t]{2}{*}{$<12$ vs. $\geq 12$} & 1.100 & 0.747 & & & 1.212 & 0.279 & 2.954 & $<0.001$ \\
\hline & $(0.616-1.965)$ & & & & $(0.856-1.718)$ & & $(1.853-4.709)$ & \\
\hline \multicolumn{9}{|l|}{ TNM stage } \\
\hline \multirow[t]{2}{*}{ I+II vs. III } & 1.593 & 0.038 & & & 2.507 & $<0.001$ & 2.253 & $<0.001$ \\
\hline & $(1.025-2.475)$ & & & & $(1.889-3.327)$ & & $(1.690-3.004)$ & \\
\hline \multicolumn{9}{|l|}{ Chemotherapy } \\
\hline \multirow[t]{2}{*}{ Yes vs. No } & 1.107 & 0.737 & & & 1.706 & 0.010 & & \\
\hline & $(0.611-2.007)$ & & & & $(1.104-2.637)$ & & & \\
\hline \multicolumn{9}{|l|}{ Serum CEA (ng/ml) } \\
\hline \multirow[t]{2}{*}{$<5$ vs. $\geq 5$} & 1.556 & 0.051 & 1.559 & 0.05 & 0.625 & 0.001 & 1.367 & 0.041 \\
\hline & $(1.003-2.416)$ & & $(1.000-2.430)$ & & $(0.472-0.828)$ & & $(1.014-1.845)$ & \\
\hline \multicolumn{9}{|l|}{ Serum CA199 (U/ml) } \\
\hline \multirow[t]{2}{*}{$<37$ vs. $\geq 37$} & 1.549 & 0.127 & & & 1.970 & $<0.001$ & 1.593 & 0.011 \\
\hline & $(0.883-2.716)$ & & & & $(1.407-2.756)$ & & $(1.112-2.281)$ & \\
\hline
\end{tabular}

diabetes have a higher risk of CRC [13-16]. In this study, we demonstrated the associations between the expression of SH2B1 and clinical manifestations in CRC. The results showed that $\mathrm{SH} 2 \mathrm{~B} 1$ expression was more elevated in CRC tissues comparing with the noncancerous colorectal tissues. SH2B1 expression in CRC was strongly associated with the differentiation grade of cancer tissues, and high SH2B1 expression predicted poor prognosis of CRC patients. In order to eliminate the influence of cancer differentiation grade, which effects the progression of cancer, we balanced this factor in multivariate Cox regression analysis and still found that high $\mathrm{SH} 2 \mathrm{~B} 1$ expression was associated with unfavorable outcomes in CRC. These results indicate that $\mathrm{SH} 2 \mathrm{~B} 1$ expression is an independent risk factor of survival for CRC patients. For patients with stage II/III CRC, adjuvant chemotherapy is the common treatment. However, the outcomes are usually unpredictable due to the heterogeneity of the response to chemotherapeutic drugs and the lack of predictive biomarkers relating to chemotherapy. Therefore, our study also focused on the contribution of $\mathrm{SH} 2 \mathrm{~B} 1$ expression to chemotherapy resistance. It was found that tumors with high SH2B1 expression were associated with poor survival outcomes in CRC patients with chemotherapy, and this association was weak in patients without chemotherapy. This result suggested that SH2B1 could be a biomarker for the prediction of CRC patients' chemotherapy response.

In recent years, $\mathrm{SH} 2 \mathrm{~B} 1$ has been found to be highly expressed in some cancers and has been demonstrated to be associated with the development of cancers [4-8]. Our results consistently suggested that $\mathrm{SH} 2 \mathrm{~B} 1$ might play an important role in the progression of CRC. And how does SH2B1 affect tumor progression? There are several views on this issue. First, it has been confirmed that $\mathrm{SH} 2 \mathrm{~B} 1$ can regulate cell migration, proliferation, and differentiation in vitro $[10,17$, 18], but the mechanism is still unclear. Second, SH2B1 may be involved in the regulation of oxidative stress, which can promote the development and progress of many aspects of cancer $[19,20]$. Third, SH2B1 serves as an adaptor protein involved in cancer development, for example, it increases the risk of cancer by promoting the transmission of leptin [21-23]. Also, SH2B1 may serve as an enhancer of tyrosine 

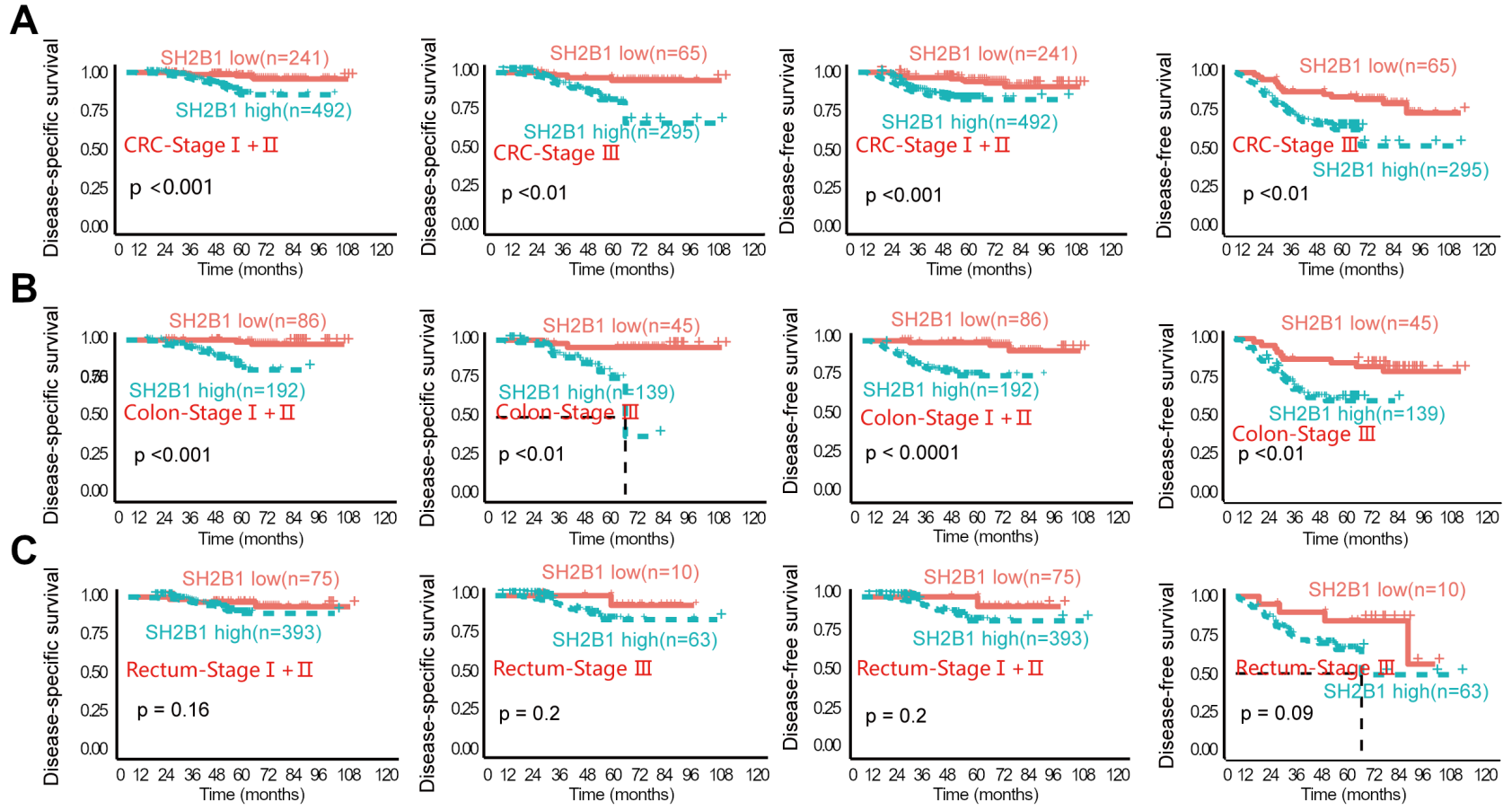

Figure 3. Kaplan-Meier survival curves showing comparisons between high and low SH2B1 expression subgroups in patients with earlier-stage CRC (stage I and II) and in patients with later-stage CRC (stage III). A) Kaplan-Meier survival curves of DFS and DSS between SH2B1-high and SH2B1-low subgroups in CRC patients. B) Kaplan-Meier survival curves of DFS and DSS between SH2B1-high and SH2B1-low subgroups in colon cancer patients. C) Kaplan-Meier survival curves of DFS and DSS between SH2B1-high and SH2B1-low subgroups in rectal cancer patients.
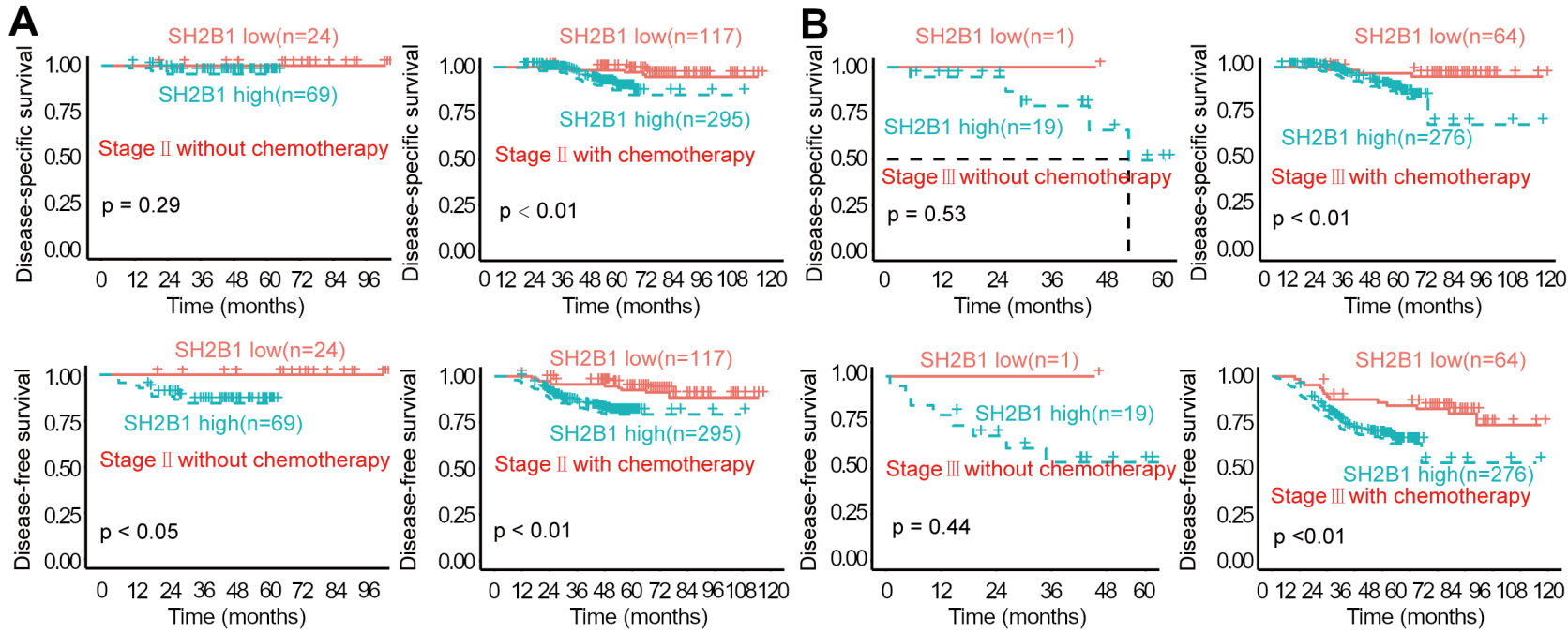

Figure 4. Kaplan-Meier survival curves showing a comparison of DFS and DSS between high and low SH2B1 expression subgroups in stage II/III CRC patients with or without chemotherapy. A) Kaplan-Meier survival curves of DFS and DSS between SH2B1-high and SH2B1-low subgroups in stage II CRC patients with or without chemotherapy. B) Kaplan-Meier survival curves of DFS and DSS between SH2B1-high and SH2B1-low subgroups in stage III CRC patients with or without chemotherapy.

kinase receptors, which participate in tumor progression by enhancing kinase activity [24-26].

In conclusion, our study evaluated the prognostic value of SH2B1 in CRC with a large cohort of CRC patients, and the results showed that $\mathrm{SH} 2 \mathrm{~B} 1$ could be a prognostic marker for CRC survival and a potential predictive biomarker for chemotherapy response. Nevertheless, the current study also has a few limitations. First, we cannot rule out the possibility of selection bias because of the loss of follow-ups. Second, some important prognostic factors were not included, such 
as microsatellite instability and extramural venous invasion, thus it may lead to an incomplete inclusion of variables in multivariate Cox analysis. Furthermore, the biological function of $\mathrm{SH} 2 \mathrm{~B} 1$ and its mechanism in CRC progression remains to be studied.

Supplementary information is available in the online version of the paper.

Acknowledgments: This work was supported by the grant from the National Natural Science Foundation of China (81774079) and sponsored by Shanghai Sailing Program (20YF1450100).

\section{References}

[1] FLORES A, ARGETSINGER LS, STADLER LKJ, MALAGA AE, VANDER PB et al. Crucial Role of the SH2B1 PH Domain for the Control of Energy Balance. Diabetes 2019; 68: 2049-2062. https://doi.org/10.2337/db19-0608

[2] JIANG L, SU H, KEOGH JM, CHEN Z, HENNING E et al. Neural deletion of $S h 2 b 1$ results in brain growth retardation and reactive aggression. FASEB J 2018; 32: 1830-1840. https://doi.org/10.1096/fj.201700831R

[3] SELVANAYAGAM T, WALKER S, GAZZELLONE MJ, KELLAM B, CYTRYNBAUM C et al. Genome-wide copy number variation analysis identifies novel candidate loci associated with pediatric obesity. Eur J Hum Genet 2018; 26: 1588-1596. https://doi.org/10.1038/s41431-018-0189-0

[4] ZHANG H, DUAN CJ, CHEN W, WANG SQ, ZHANG SK et al. Clinical significance of SH2B1 adaptor protein expression in non-small cell lung cancer. Asian Pac J Cancer Prev 2012; 13: 2355-2362. https://doi.org/10.7314/apjcp.2012.13.5.2355

[5] WANG S, ZHENG Y, HE Z, ZHOU W, CHENG Y et al. SH2B1 promotes NSCLC cell proliferation through PI3K/ Akt/mTOR signaling cascade. Cancer Cell Int 2018; 18: 132. https://doi.org/10.1186/s12935-018-0632-x

[6] Ohtsuka S, Takaki S, Iseki M, Miyoshi K, Nakagata N et al. $\mathrm{SH} 2-\mathrm{B}$ is required for both male and female reproduction. Mol Cell Biol 2002; 22: 3066-3077. https://doi.org/10.1128/ mcb.22.9.3066-3077.2002

[7] LIU B, LI F, ZHAO HP, CHEN JB, LI YP et al. miR-874 inhibits metastasis-relevant traits via targeting $\mathrm{SH} 2 \mathrm{~B}$ adaptor protein 1 (SH2B1) in gastric cancer. Int J Clin Exp Pathol 2017; 10: 8577-8584.

[8] LIU J, ZHU J, XIAO Z, WANG X, LUO J. BBOX1-AS1 contributes to colorectal cancer progression by sponging hsamiR-361-3p and targeting SH2B1. FEBS Open Bio 2020. https://doi.org/10.1002/2211-5463.12802

[9] CHENG Y, DUAN C, ZHANG C. New perspective on SH2B1: An accelerator of cancer progression. Biomed Pharmacother 2020; 121: 109651. https://doi.org/10.1016/j.biopha.2019.109651

[10] JIN C, WANG A, LIU L, WANG G, LI G. Hsa_circ_0136666 promotes the proliferation and invasion of colorectal cancer through miR-136/SH2B1 axis. J Cell Physiol 2019; 234: 7247-7256. https://doi.org/10.1002/jcp.27482
[11] SONG M, LI Y, MIAO M, ZHANG F, YUAN H et al. High stromal nicotinamide N-methyltransferase (NNMT) indicates poor prognosis in colorectal cancer. Cancer Med 2020; 9: 2030-2038. https://doi.org/10.1002/cam4.2890

[12] RUI L. SH2B1 regulation of energy balance, body weight, and glucose metabolism. World J Diabetes 2014; 5: 511-526. https://doi.org/10.4239/wjd.v5.i4.511

[13] AL-EITAN LN, AMAN H, ALKHATIB R, ALGHAMDI MA. Genetic Association of SH2B1 Gene Polymorphisms in Jordanian Arab Patients with Type 2 Diabetes Mellitus. Diabetes Metab Syndr Obes 2020; 13: 1825-1834. https://doi. org/10.2147/DMSO.S245843

[14] KHAW KT, WAREHAM N, BINGHAM S, LUBEN R, WELCH A et al. Preliminary communication: glycated hemoglobin, diabetes, and incident colorectal cancer in men and women: a prospective analysis from the European prospective investigation into cancer-Norfolk study. Cancer Epidemiol Biomarkers Prev 2004; 13: 915-919.

[15] HUANG HE, YANG YC, WU JS, WANG RH, LU FH et al. The relationship between different glycemic statuses and colon polyps in a Taiwanese population. J Gastroenterol 2014; 49: 1145-1151. https://doi.org/10.1007/s00535-013-0863-5

[16] DE KORT S, BOUWENS MW, WEIJENBERG MP, JANSSEN-HEIJNEN ML, DE BRUÏNE AP et al. Significantly higher rates of multiple and proximally located adenomas among patients with diabetes mellitus: A cross-sectional population-based study. United European Gastroenterol J 2017; 5: 415-423. https://doi.org/10.1177/2050640616664271

[17] WANG S, CHENG Y, GAO Y, HE Z, ZHOU W et al. SH2B1 promotes epithelial-mesenchymal transition through the IRS $1 / \beta$-catenin signaling axis in lung adenocarcinoma. Mol Carcinog 2018; 57: 640-652. https://doi.org/10.1002/ mc. 22788

[18] LIU B, LI F, ZHAO HP, CHEN JB, LI YP et al. Circulating $\mathrm{SH} 2 \mathrm{~B} 1$ is associated with an increased risk of gastric cancer. Oncol Lett 2018; 15: 7305-7311. https://doi.org/10.3892/ ol.2018.8196

[19] SOSA V, MOLINÉ T, SOMOZA R, PACIUCCI R, KON$\mathrm{DOH} H$ et al. Oxidative stress and cancer: an overview. Ageing Res Rev 2013; 12: 376-390. https://doi.org/10.1016/j. arr.2012.10.004

[20] LU WC, CHEN CJ, HSU HC, HSU HL, CHEN L. The adaptor protein $\mathrm{SH} 2 \mathrm{~B} 1 \beta$ reduces hydrogen peroxide-induced cell death in PC12 cells and hippocampal neurons. J Mol Signal 2010; 5: 17. https://doi.org/10.1186/1750-2187-5-17

[21] NIU J, JIANG L, GUO W, SHAO L, LIU Y et al. The association between leptin level and breast cancer: a meta-analysis. PLoS One 2013; 8: e67349. https://doi.org/10.1371/journal. pone.0067349

[22] MULLEN M, GONZALEZ-PEREZ RR. Leptin-induced JAK/STAT signaling and cancer growth. Vaccines (Basel) 2016; 4: 26. https://doi.org/10.3390/vaccines4030026

[23] KORD-VARKANEH H, FATAHI S, ALIZADEH S, GHAEDI E, SHAB-BIDAR S. Association of serum leptin with all-cause and disease specific mortality: a meta-analysis of prospective observational studies. Horm Metab Res 2018; 50: 509-520. https://doi.org/10.1055/a-0620-8671 
[24] KONG M, WANG CS, DONOGHUE DJ. Interaction of fibroblast growth factor receptor 3 and the adapter protein SH2-B. A role in STAT5 activation. J Biol Chem 2002; 277: 15962-15970. https://doi.org/10.1074/jbc.M102777200

[25] DEMOULIN JB, ESSAGHIR A. PDGF receptor signaling networks in normal and cancer cells. Cytokine Growth Factor Rev 2014; 25: 273-283. https://doi.org/10.1016/j.cytogfr.2014.03.003
[26] HUANG F, WANG M, YANG T, CAI J, ZHANG Q et al. Gastric cancer-derived MSC-secreted PDGF-DD promotes gastric cancer progression. J Cancer Res Clin Oncol 2014; 140: 1835-1848. https://doi.org/10.1007/s00432-014-1723-2 
https://doi.org/10.4149/neo_2021_201015N1092

\section{High expression of SH2B adaptor protein 1 (SH2B1) indicates poor prognosis in colorectal cancer}

Linxi ZHANG ${ }^{1, *}$, Xiaowen XU ${ }^{1, *}$, Yamin PAN ${ }^{1, *}$, Fuao $\mathrm{CAO}^{2, *}$

\section{Supplementary Information}

Supplementary Table S1. Cox regression analysis of immunohistochemistry SH2B1 expression and clinicopathological covariates in the colon cancer patients.

\begin{tabular}{|c|c|c|c|c|c|c|c|c|}
\hline \multirow{3}{*}{ Variables } & \multicolumn{4}{|c|}{ Disease-specific survival } & \multicolumn{4}{|c|}{$\begin{array}{c}\text { Disease-free survival } \\
\end{array}$} \\
\hline & \multicolumn{2}{|c|}{ Univariate analysis } & \multicolumn{2}{|c|}{ Multivariate analysis } & \multicolumn{2}{|c|}{ Univariate analysis } & \multicolumn{2}{|c|}{ Multivariate analysis } \\
\hline & HR $(95 \% \mathrm{CI})$ & p-value & HR $(95 \% \mathrm{CI})$ & p-value & HR $(95 \%$ CI $)$ & p-value & HR $(95 \% \mathrm{CI})$ & p-value \\
\hline \multicolumn{9}{|l|}{ Age } \\
\hline \multirow[t]{2}{*}{$>60$ vs. $\leq 60$} & 0.980 & 0.950 & & & 1.094 & 0.662 & & \\
\hline & $(0.531-1.812)$ & & & & $(0.730-1.640)$ & & & \\
\hline \multicolumn{9}{|l|}{ Sex } \\
\hline \multirow[t]{2}{*}{ Male vs. Female } & 0.858 & 0.625 & & & 0.982 & 0.929 & & \\
\hline & $(0.461-1.596)$ & & & & $(0.656-1.470)$ & & & \\
\hline \multicolumn{9}{|l|}{ Differential grade } \\
\hline \multirow[t]{2}{*}{ (Well+Moderate) vs. Poor } & 0.861 & 0.720 & & & 0.852 & 0.560 & & \\
\hline & $(0.380-1.951)$ & & & & $(0.497-1.460)$ & & & \\
\hline \multicolumn{9}{|l|}{ Lymph nodes, n (\%) } \\
\hline \multirow[t]{2}{*}{$<12$ vs. $\geq 12$} & 0.870 & 0.713 & & & 0.925 & 0.745 & & \\
\hline & $(0.415-1.826)$ & & & & $(0.579-1.479)$ & & & \\
\hline \multicolumn{9}{|l|}{ TNM stage } \\
\hline \multirow[t]{2}{*}{ I+II vs. III } & 1.594 & 0.138 & & & 2.393 & $<0.001$ & 2.144 & $<0.001$ \\
\hline & $(0.862-2.947)$ & & & & $(1.593-3.594)$ & & $(1.383-3.324)$ & \\
\hline \multicolumn{9}{|l|}{ Chemotherapy } \\
\hline \multirow[t]{2}{*}{ Yes vs. No } & 1.400 & 0.446 & & & 1.750 & 0.070 & & \\
\hline & $(0.589-3.329)$ & & & & $(0.955-3.204)$ & & & \\
\hline \multicolumn{9}{|l|}{ Serum CEA (ng/ml) } \\
\hline \multirow[t]{2}{*}{$<5$ vs. $\geq 5$} & 1.326 & 0.368 & & & 1.406 & 0.0952 & & \\
\hline & $(0.718-2.450)$ & & & & $(0.942-2.099)$ & & & \\
\hline \multicolumn{9}{|l|}{ Serum CA199 (U/ml) } \\
\hline \multirow[t]{2}{*}{$<37$ vs. $\geq 37$} & 1.191 & 0.658 & & & 1.756 & 0.016 & & \\
\hline & $(0.550-2.578)$ & & & & $(1.113-2.771)$ & & & \\
\hline \multicolumn{9}{|l|}{ SH2B1 } \\
\hline \multirow[t]{2}{*}{ Low vs. High } & 10.40 & $<0.001$ & 10.34 & $<0.001$ & 4.903 & $<0.001$ & 5.000 & $<0.001$ \\
\hline & $(3.321-32.583)$ & & $(3.256-32.843)$ & & $(2.507-9.587)$ & & $(2.457-10.174)$ & \\
\hline
\end{tabular}


Supplementary Table S2. Cox regression analysis of immunohistochemistry SH2B1 expression and clinicopathological covariates in the rectal cancer patients.

\begin{tabular}{|c|c|c|c|c|c|c|c|c|}
\hline \multirow{3}{*}{ Variables } & \multicolumn{4}{|c|}{ Disease-specific survival } & \multicolumn{4}{|c|}{ Disease-free survival } \\
\hline & \multicolumn{2}{|c|}{ Univariate analysis } & \multicolumn{2}{|c|}{ Multivariate analysis } & \multicolumn{2}{|c|}{ Univariate analysis } & \multicolumn{2}{|c|}{ Multivariate analysis } \\
\hline & HR $(95 \% \mathrm{CI})$ & p-value & HR $(95 \% \mathrm{CI})$ & p-value & HR (95\% CI) & p-value & HR $(95 \% \mathrm{CI})$ & p-value \\
\hline \multicolumn{9}{|l|}{ Age } \\
\hline \multirow[t]{2}{*}{$>60$ vs. $\leq 60$} & 0.913 & 0.777 & & & 0.774 & 0.208 & & \\
\hline & $(0.486-1.714)$ & & & & $(0.520-1.153)$ & & & \\
\hline \multicolumn{9}{|l|}{ Sex } \\
\hline \multirow[t]{2}{*}{ Male vs. Female } & 0.802 & 0.518 & & & 0.840 & 0.412 & & \\
\hline & $(0.412-1.563)$ & & & & $(0.555-1.273)$ & & & \\
\hline \multicolumn{9}{|l|}{ Differential grade } \\
\hline \multirow[t]{2}{*}{ (Well+Moderate) vs. Poor } & 0.694 & 0.616 & & & 1.029 & 0.941 & & \\
\hline & $(0.166-2.903)$ & & & & $(0.476-2.226)$ & & & \\
\hline \multicolumn{9}{|l|}{ Lymph nodes, n (\%) } \\
\hline \multirow[t]{2}{*}{$<12$ vs. $\geq 12$} & 1.584 & 0.341 & & & 1.737 & 0.040 & 1.567 & 0.014 \\
\hline & $(0.615-4.083)$ & & & & $(1.026-2.939)$ & & $(1.148-3.361)$ & \\
\hline \multicolumn{9}{|l|}{ TNM stage } \\
\hline \multirow[t]{2}{*}{ I+II vs. III } & 1.553 & 0.174 & & & 2.564 & $<0.001$ & 2.646 & $<0.001$ \\
\hline & $(0.824-2.925)$ & & & & $(1.727-3.807)$ & & $(1.771-3.952)$ & \\
\hline \multicolumn{9}{|l|}{ Chemotherapy } \\
\hline \multirow[t]{2}{*}{ Yes vs. No } & 0.878 & 0.755 & & & 1.666 & 0.111 & & \\
\hline & $(0.386-1.997)$ & & & & $(0.889-3.121)$ & & & \\
\hline \multicolumn{9}{|l|}{ Serum CEA (ng/ml) } \\
\hline \multirow[t]{2}{*}{$<5$ vs. $\geq 5$} & 1.811 & 0.065 & & & 1.789 & 0.004 & 1.567 & 0.028 \\
\hline & $(0.964-3.403)$ & & & & $(1.205-2.657)$ & & $(1.048-2.343)$ & \\
\hline \multicolumn{9}{|l|}{ Serum CA199 (U/ml) } \\
\hline \multirow[t]{2}{*}{$<37$ vs. $\geq 37$} & 2.101 & 0.076 & & & 2.228 & 0.002 & & \\
\hline & $(0.926-4.768)$ & & & & $(1.350-3.678)$ & & & \\
\hline \multicolumn{9}{|l|}{ SH2B1 } \\
\hline \multirow[t]{2}{*}{ Low vs. High } & 2.949 & 0.058 & & & 2.040 & 0.033 & & \\
\hline & $(0.965-9.014)$ & & & & $(1.058-3.934)$ & & & \\
\hline
\end{tabular}

